\title{
Using Moodle in a General Education English as a Second Language Program: Taiwanese College Student Experiences and Perspectives
}

\author{
Chia-Hui Lin \\ Toko University, Taiwan \\ E-mail:Tinalin26@hotmail.com
}

\section{Doi:10.5901/jesr.2013.v3n3p97}

\begin{abstract}
Pascarella and Terenzini (1991) concluded that general education improves students' critical thinking. General education English courses have used the Modular Object-Oriented Dynamic Learning Environment (Moodle) platform for more than a decade. Moodle has become a popular free software package to assist educators and researchers in harnessing the benefits of online learning communities. This study uses a non-experimental, quantitative SPSS 17.0 research design to explore the relationship among demographic characteristics, Moodle use, flexible learning, and English as a second language (ESL) learning outcomes. The accessible population sample consisted of 231 participants, resulting in a response rate of $87 \%$. The participants were college students from 2 colleges in Taiwan. The results show that Hypothesis 1 was supported for all variables for the ESL outcome $(p=.0)$. Hypothesis 2 was supported for all variables for the pretest and posttest outcomes $(p=$ .0). Hypothesis 3 was supported for Moodle use and flexible learning with Moodle $(p=.0)$. Hypothesis 4 was not supported, and for general English, the posttest outcome explained more variance than the pretest outcome. Hypothesis 5 was not supported for Moodle use and the general English and English outcomes. The results of this study have limited applicability because the participants were from 2 small colleges. The distribution of the groups was also irregular. Although the results are valid, they should not be overgeneralized to the whole population. Future studies on general education English should sample all colleges in Taiwan.
\end{abstract}

Keywords: general education, English as a second language, Moodle, flexible education learning

\section{Introduction}

All general education programs share similar goals: creating experiences, communicating skill sets, and fostering knowledge important to all students. General education was implemented at Yale University in 1828 (Kanter, Gamson, \& London, 1997). The Harvard model developed on the general education model. The Harvard Report of 1945 and the Yale Report of 1828 stated that the purpose of general education was to improve student spiritual nurturing and to foster their communication, thinking, value cognition, and judgment.

The Yale Report of 1828 consists of two parts: a general discussion of the nature of liberal education and an argument for retaining Greek and Latin in the college curriculum (Bryant, 1945; Committee of the Corporation and the Academic Faculty, 1828). Harvard University launched its reformed General Education Curriculum in 2007 and mentioned that the general education model was used in many international universities. General education courses provide a liberal arts foundation and cultivate open minds in students who appreciate their value (Voparil, 2007).

General education English courses have used the Modular Object-Oriented Dynamic Learning Environment (Moodle) platform for more than a decade. Moodle has become a popular free software package to assist educators and researchers in harnessing the benefits of online learning communities. Since April 9, 2011, Moodle has been used on more than 54,466 sites in 213 countries in 70 languages. Moodle has 41,524,927 users, 1,137,626 of whom are teachers who coordinate 4,410,988 courses (Kennedy, 2005; Aranda, 2011; Moodle, 2011b). Open source systems-which provide management functions for multimedia materials, interactive communication, and learning records-are particularly useful for general education English courses (Nozawa, 2011). This study uses the Moodle platform to teach undergraduate students English using a flexible education perspective.

Many Taiwanese students are too shy or scared to learn or speak English in the classroom. This is because Taiwan is an island, and students have few opportunities to converse in English with foreigners. This study uses Moodle and e-learning to assist college students by creating an efficient alternative method of learning English to stimulate communication among participants. 


\section{Literature Review and Hypothesis Development}

\subsection{General education}

Pascarella and Terenzini (1991) concluded that general education improves students' critical thinking. General education helps college students understand that they are not people who are separate from society, but rather, members of a larger community. Boyer described general education as "significant when it shows us who we are as individuals and as citizens, and touches the hopes and fears that make each of us both unique beings and a part of corporate humanity" (1987, p. 98). Harvard University has developed general education since 1945, and its general education program has four goals:

1. to prepare students for civic engagement;

2. to teach students to understand themselves as products of, and participants in, traditions of art, ideas, and values;

3. to enable students to respond critically and constructively to change;

4. and to develop students' understanding of the ethical dimensions of what they say and do.

(Report of the Test Force on General Education, 2007).

Harvard University also has eight subject categories that are university requirements:

- Aesthetic and Interpretive Understanding

- Culture and Belief

- Empirical Reasoning

- Ethical Reasoning

- Science of Living Systems

- Science of the Physical Universe

- Societies of the World

- The United States in the World

(Report of the Committee on General Education, 2005)

Newton (2000) described the three dominant models of general education used in the United States as the scholarly discipline model, the great books model, and the effective citizen model. Additionally, four analytical elements have been present in U.S. conceptual frameworks of general education since the last half of the twentieth century: (a) general education as a cultural movement and curricular structure; (b) the origin and diffusion of competing models; (c) forces and agents of change; and (d) course-level adaptions (Brint, Proctor, Murphy, Bicakci, \& Hanneman, 2009). Student-centered Internet tools have been developed to promote knowledge and general education learning. E-learning platforms are flexible, accessible, and encourage student interaction. The Moodle platform is commonly used by international universities, schools, communities, instructors, and businesses as an online learning tool (Lopes, 2011).

\subsection{Moodle}

Dougiamas (1998) developed Moodle for educators based on a social constructionist pedagogical philosophy. Moodle is a course or learning management system and is used to service several students at universities and schools. Moodle is a free web application educators can use to create effective online sites (Lopes, 2011). Cole and Foster referred to Moodle as "a verb that describes the process of lazily meandering through something, an enjoyable tinkering that often leads to insights and creativity" (2008, p. ix). Moodle has many features such as assignments, chats, forums, surveys, quizzes, and glossaries (Franco, 2010). Dougiamas created Moodle as a flexible, compatible, and easy-to-modify system (Dougiamas \& Taylor, 2003). According to Dougiamas (1999), teachers should be involved in course activities to monitor, stimulate, and engage students in discussion and access student assignments, journals, quizzes, chat rooms, and workshops (Mark, 2009).

Moodle is based on a constructivist and social constructionist approach to education emphasizing that learners can contribute to the educational experience in many ways (Wu, 2008). Moodle includes flexible features such as, layout, course management, assessment strategy quizzes, and cooperative learning (Wu, 2008).

The Moodle design and components are based on the constructivist theory of learning "to provide a set of tools that support an inquiry-and-discovery-based approach to online learning" (Brandi, 2005, p. 16). Williams (2005) explained the four main concepts that the Moodle learning philosophy is based on: (a) constructivism—people construct new knowledge from their learning environments; (b) constructionism-learning is particularly effective for people; (c) social 
constructivism-a concept based on cooperation; and (d) connected and separate behavior-a concept based on people's participation in discussions. The Moodle platform can benefit student-teacher interactions, foster student independence, and allow students more flexible time for learning.

\subsection{Flexible learning}

ANTA (1992) defined flexible learning as follows:

An approach to vocational education and training which allows for the adoption of a range of learning strategies in a variety of learning environments to cater for differences in learning styles, learning interests and needs, and variations in learning opportunities.

Flexible learning is an approach that provides learners with various opportunities to focus more on learning requirements and individual learning circumstances (Gearhart, 2008). The Australian Flexible Learning Framework stated that flexible learning "expands choices of what, when, where and how people learn, while also supporting different styles of learning, including e-learning" (2005, p.1). Moore and Kearsley (1996) created a flexible learning framework. Their model, shown in Figure 1, illustrates the most important connections between factors.

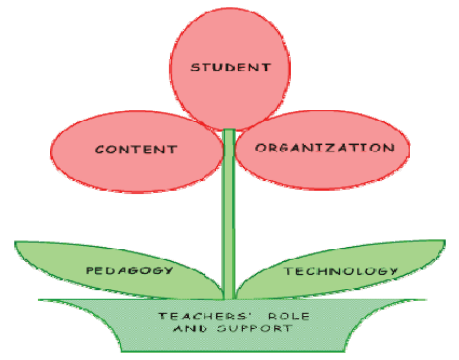

Figure1: A framework of flexible learning

Flexible learning also includes nine normative characteristics that feature in the educational process: (a) an emphasis on meeting client requirements, (b) greater client choice in selecting the whats of training, (c) greater flexibility in the wheres and whens of training, (d) greater variety in the hows of training, (e) a shift in the role of the teacher from a director to a facilitator of learning, (f) more flexible organizational support systems and structures, (g) processes that integrate elements, (h) using appropriate technology to support learning, and (i) collaboration and strategic alliances to encourage sharing experiences (James, Louise, \& Jane, 2001).

\subsection{English as a second language learning outcomes}

English as a second language (ESL) programs can fulfill student emotional requirements and provide them with a positive educational experience (Smith, 2009). Second language acquisition includes five primary linguistic elements: phonology, syntax, morphology, semantics, and pragmatics. Three second language acquisition models exist: the Universal Grammar Model, the Competition Model, and the Monitor Model. These models are based on five hypotheses: the Acquisition-Learning Hypothesis; the Natural Order Hypothesis; the Monitor Hypothesis; the Input Hypothesis; and the Affective Filter Hypothesis (Chomsky, 1975; Bates \& MacWhinney, 1982; Krashen, 1985). Baker (2006) studied successful bilingual programs and concluded that good programs cultivate skills that enable learners to listen, speak, read, and write in two languages. Several studies have demonstrated that English language learners who receive first language instruction from strong bilingual programs perform better and exhibit higher levels of English proficiency (Cloud, Genesee, \& Hayaman, 2000).

\section{Hypothesis Development and Methodology}




\subsection{Research question and hypotheses}

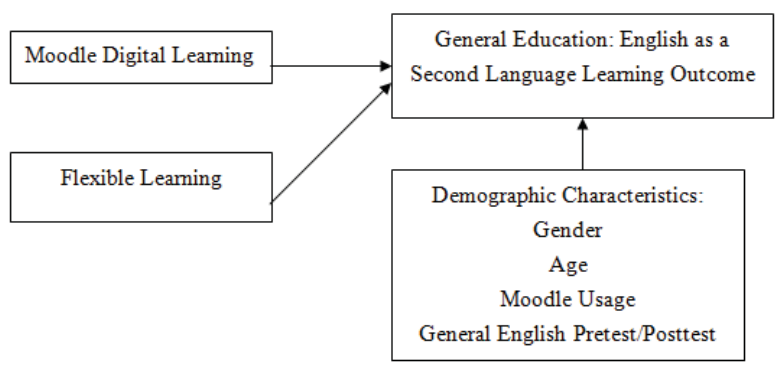

Fig. 2: Hypothesized model of background characteristics, Moodle learning, flexible learning, and English as a second language learning outcome.

\subsection{Hypotheses}

- H1: Moodle use (with or without Moodle), flexible learning, and demographic characteristics (age, gender) are significant explanatory variables of ESL learning outcomes.

- H2: Moodle use, flexible learning, and ESL learning outcomes are statistically significant for general English pretest and posttest outcomes.

- H3: Moodle use and flexible learning with Moodle explain more of the ESL learning outcomes than Moodle use and flexible learning without Moodle.

- H4: The general education English posttest explains more of the relationship between Moodle use, flexible learning, and ESL learning outcomes than the general education English pretest.

- H5: Moodle use (with and or without Moodle) and general education English (pretest and posttest) significantly affect second language learning outcomes.

\subsection{Research design}

A non-experimental, quantitative SPSS 17.0 research design was used to explore the relationship among demographic characteristics, Moodle use, flexible learning, and ESL learning outcomes.

\subsection{Population and sampling}

\subsubsection{Target population}

According to the Taiwanese Ministry of Education Department of Statistics (2011), over 100,000 students have completed the national university entrance exam. This means that approximately $66.6 \%$ of students register at universities. Since the 1990s, many junior colleges and trade schools have been promoted to universities. The target population in this study consisted of 177 college students in Taiwan. The sample included students enrolled in the National Taichung University of Education and Toko University.

\subsubsection{Sampling plan}

The total target population included 231 students who were invited to participate in the study. However, the final dataproducing sample depended on which students agreed to participate in the study. 
The survey instrument used in this study consisted of four parts: (a) a Background Demographic Characteristics survey developed by the researchers, (b) the Flexible Education survey developed by the Institute of Teaching and Learning (2009); (c) the Moodle Learning survey developed by Kanninen (2008); and (d) the General Education Program: Learning Outcome survey developed by Missouri Valley College (2011).

\section{Results}

\subsection{Multiple regressions analysis: Hypothesis 1}

The value of significance $(p=.0)$ in Table 1 indicates a statistically significant result. Therefore, the results support Research Hypothesis 1.

Table 1. ANOVA for Multiple Regression Analyses of Background Demographic Characteristics, Moodle learning, flexible learning, and English as a second language learning outcome.

\begin{tabular}{|c|c|c|c|c|c|c|}
\hline & Model & $\begin{array}{l}\text { Sum of } \\
\text { Squares }\end{array}$ & $d f$ & $\begin{array}{c}\text { Mean } \\
\text { Square }\end{array}$ & $F$ & Sig. \\
\hline \multirow[t]{3}{*}{1} & Regression & 55.823 & 5 & 11.165 & 26.967 & $.000(a)$ \\
\hline & Residual & 93.151 & 225 & .414 & & \\
\hline & Total & 148.974 & 230 & & & \\
\hline
\end{tabular}

\subsection{One-way ANCOVA: Hypothesis 2}

The value of significance $(p=.0)$ in Table 2 indicates a statistically significant result. Therefore, the results support Research Hypothesis 2.

Table 2. One-way ANCOVA with Moodle learning, flexible learning, English as a second language learning outcome, and with General English Pre-Test and Post-Test

\begin{tabular}{lccccc}
\hline \multicolumn{1}{c}{ Source } & $\begin{array}{c}\text { Type III Sum of } \\
\text { Squares }\end{array}$ & df & Mean Square & F & Sig. \\
\hline Corrected Model & $472034.245(\mathrm{a})$ & 199 & 2372.031 & 4.246 & .000 \\
Intercept & 16451.445 & 1 & 16451.445 & 29.448 & .000 \\
$\begin{array}{l}\text { FlexibleEducationAVG * } \\
\text { MoodleAVG * }\end{array}$ & 472034.245 & 199 & 2372.031 & 4.246 & .000 \\
LearningOutcomeAVG * Pretest & 17318.750 & 31 & 558.669 & & \\
Error & 4040961.000 & 231 & & & \\
Total & 489352.996 & 230 & & &
\end{tabular}

\subsection{R-squared analysis: Hypothesis 2 and Hypothesis 3}

Table 3 shows that the $R$-squared value of the model accounts for $37.7 \%$ of the variation when students used Moodle and $33.5 \%$ of the variation when students did not use Moodle. These results support Research Hypothesis 3.

Table 3. Multiple Regression R Square Analyses of Moodle learning, flexible learning, English as a second language learning outcome, and Moodle Usage(with and without)

\begin{tabular}{|c|c|c|c|c|c|}
\hline & Model & $R$ & $R$ Square & $\begin{array}{l}\text { Adjusted } \\
R \text { Square }\end{array}$ & $\begin{array}{l}\text { Std. Error of the } \\
\text { Estimate }\end{array}$ \\
\hline Moodle Usage & 1 & $.614 a)$ & .377 & .371 & .641 \\
\hline Without Usage & 2 & $.578(\mathrm{a})$ & .335 & .287 & .658 \\
\hline
\end{tabular}


Table 4 shows that the $R$-squared value of the model accounts for $0.4 \%$ of the posttest variation and $3.5 \%$ of the pretest variation. These results do not support Research Hypothesis 4.

Table 4. Multiple Regression R Square Analyses of Moodle learning, flexible learning, English as a second language learning outcome, and General English with posttest and pretest.

\begin{tabular}{rccccc}
\hline & Model & $R$ & $R$ Square & Adjusted $R$ Square & Std. Error of the Estimate \\
\hline Posttest & 1 & $.067 a)$ & .004 & .009 & 46.327 \\
Pretest & 2 & $.187(\mathrm{a})$ & .035 & .022 & 45.140 \\
\hline
\end{tabular}

\subsection{Two-way ANOVA: Hypothesis 5}

The value of significance $(p=.749)$ in Table 5 indicates a statistically significant result. This result does not support Research Hypothesis 5.

Table 5. Two-Way ANOVA of Moodle usage (with and without), General English with (pretest and posttest), and second language learning outcome.

\begin{tabular}{ccccccc}
\hline Model & & Sum of Squares & df & Mean Square & F & Sig. \\
\hline \multirow{2}{*}{1} & Regression & .795 & 3 & .265 & .406 & $.749(\mathrm{a})$ \\
& Residual & 148.179 & 227 & .653 & & \\
& Total & 148.974 & 230 & & & \\
& & & &
\end{tabular}

\subsection{Reliability analysis}

Table 6 shows that Cronbach's alpha value for internal consistency for all variables was 0.916 . This indicates an acceptable level of reliability. All variables produced Cronbach's alpha values of more than 0.7 , indicating satisfactory internal consistency.

Table 6. Reliability Statistics for Demographic Characteristics, Moodle learning, flexible learning, English as a second language learning outcome.

\begin{tabular}{cc}
\hline Cronbach's Alpha & N of Items \\
\hline .916 & 22 \\
\hline
\end{tabular}

\subsection{Factor analysis for construct validity}

Table 7 shows the results for the Kaiser Meyer Olkin (KMO) measure and Bartlett's test of sphericity. The KMO values were 0.874 for flexible education, 0.86 for Moodle use, and 0.891 for English learning outcome.

Table 7. KMO and Bartlett's Test Results on Moodle learning, flexible learning, English as a second language learning outcome

\begin{tabular}{ccc}
\hline $\begin{array}{c}\text { Kaiser-Meyer-Olkin Measure of } \\
\text { Sampling Adequacy }\end{array}$ & .874 \\
\hline Bartlett's Test of Sphericity & .860 & \\
& .891 & 664.878 \\
& & 475.167 \\
& Approx. Chi-Square & 911.735 \\
& & 21 \\
& Sig. & 10 \\
& & .000 \\
& & .000 \\
\hline
\end{tabular}


Table 8 shows that one-factor values were larger after varimax rotation was extracted, accounting for approximately $56 \%$ of the total variance.

Table 8. Extraction Sums of Squared Loading on Flexible Education

\begin{tabular}{cccc}
\hline $\begin{array}{c}\text { Compon } \\
\text { ent }\end{array}$ & Extraction Sums of & & \\
\hline & Squared Loadings & & \\
1 & Total & $\%$ of Variance & Cumulative \% \\
\hline
\end{tabular}

Table 9 shows that one-factor values were larger after varimax rotation was extracted, accounting for approximately $64 \%$ of the total variance.

Table 9. Extraction Sums of Squared Loading on Moodle

\begin{tabular}{cccc}
\hline \multirow{2}{*}{ Component } & Extraction Sums of & & \\
& Squared Loadings & & \\
\hline \multirow{2}{*}{1} & Total & \% of Variance & Cumulative \% \\
& 3.190 & 63.804 & 63.804 \\
\hline
\end{tabular}

Table 10 shows that one-factor values were larger after varimax rotation was extracted, accounting for approximately $64 \%$ of the total variance.

Table 10. Extraction Sums of Squared Loading on English Learning Outcome

\begin{tabular}{cccc}
\hline \multirow{2}{*}{ Component } & Extraction Sums of & & \\
& Squared Loadings & & \\
\hline \multirow{2}{*}{1} & Total & \% of Variance & Cumulative \% \\
& 4.461 & 63.735 & 63.735 \\
\hline
\end{tabular}

\section{Conclusion}

The target population consisted of 231 participants, producing a response rate of $87 \%$. The participants were college students from two colleges in Taiwan. The results support Hypothesis 1 for all variables for the ESL outcome $(p=.0)$. The results support Hypothesis 2 for all variables for the general education English pretest and posttest $(p=.0)$. The results support Hypothesis 3 for Moodle use and flexible learning with Moodle. Hypothesis 4 was not supported, and the general education English posttest explained more variance than the pretest. Hypothesis 5 was not supported for Moodle use and general education English and English outcomes.

\section{Practical Implications}

Moodle and flexible learning may benefit Taiwanese students learning English. The results of this study show that Taiwanese college students preferred using Moodle for computer language learning. However, students' posttest and pretest results did not significantly affect their English outcomes. The findings of this study are important to the Taiwanese government, educational institutes, students, and other researchers who may benefit from the information on Moodle and flexible learning. Educational institutions could use the results to support and focus more on student language learning to increase student motivation.

\section{Limitations and Future Studies}

The results of the study have limited applicability because the participants were from two small colleges in two cities. The distribution of the groups was also irregular. Although the results are valid, they should not be generalized to the whole population. Future studies on general education English should sample all colleges in Taiwan. 


\section{References:}

Aranda, A. D. (2011). Moodle for distance education. Distance Learning, 8(2), 25-28. Retrieved October 29, 2012, from ProQuest database.

Australian Flexible Learning Framework. (2005). What is flexible learning? Retrieved November 1, 2012, from http://pre2005.flexiblelearning.net.au/aboutus/

Baker, C. (2006). Foundations of bilingual education and bilingualism (4th ed). Clevedon,UK: Multilingual Matters LTD.

Bates, E., \& MacWhinney, B. (1982). Functionalist approaches to grammar. In E. Wanner \& L. R. Gleitman (Eds.), Language acquisition: The state of the art (pp. 173-218). New York: Cambridge University Press.

BOYER, E. (1987). College: The Undergraduate Experience in America. Princeton, NJ: Carnegie Foundation for the Advancement of Teaching.

Brandi, K. (2005). Are you ready to "Moodle"? Language Learning \& Technology, 9(2), 16-23

Bryant, J. (1945). General Education in a free society report of the Harvard committee. Harvard University Press.

Brint, S., Proctor, K., Murphy, S.P., Bicakci, L.T., Hanneman, R. A. (2009). General education model: Continuity and change in the U.S. undergraduate curriculu, 1975-2000. The Journal of Higher Education, 80(6), 605-642.

Chomsky, N. (1975). Reflections on language (1st ed.). New York: Pantheon Books.

Cole, J. \& Foster, H. (2008). Using Moodle: teaching with the popular open source management system. $2^{\text {nd }}$. Ed. Sebastopol, CA: O'Reilly Community Press.

Committee of the Corporation and the Academic Faculty. (1828). Course of Instruction in Yale College. New Haven.

Cloud, N., Genesee, F., Hamayan, E. (2000). Dual language instruction: A handbook for enriched education. Boston, MA: Heinle \& Heinle.

Dougiamas, M. (1998). A journey in constructivism. Retrieved October. 17, 2012, from http://dougiamas.com/writing/constructivism

Dougiamas, M. (1999). Reading and writing for internet teaching. Retrieved October 24, 2012, from http://dougiamas.com /writing/readwrite.html

Dougiamas, M., \& Taylor, R C. (2003). Moodle: Using learning communities to create an open source course management system. Proceedings of the EDMEDIA 2003 Conference, Honolulu, HI.

Franco, C. D. P. (2010). Moodle as an alternative to flexible education. Education On Line, 1(1), 1-15.

Gearhart, D. (2008). Understanding flexible learning theory and how it is used in online learning. Retrieved November 1, 2012, from http://www.irma-international.org/viewtitle/30555/

James, S. R., Louise, M., \& Jane, S. (2001). Scope of flexible learning and implications for improved data collection and reporting systems. Retrieved November 14, 2012, from http://pre2005.flexiblelearning.net.au/pif/OP239FinalReport.doc

Kanter, S. L., Gamson, Z. F., \& London, H. B. (1997). Revitalizing general education in a time of scarcity. Boston: Allyn and Bacon

Krashen, S. D. (1985). The input hypothesis: Issues and implications. White Plains, NY: Longman

Lopes, A. P. (2011). Teaching with Moodle in Higher Education. Paper Presented at the $5^{\text {th }}$ International Technology, Education and Development Conference, Valencia, Spain.

Mark, L. (2009). Using Moodle. TechTrends, 53(1), 91. Retrieved October 31, 2012, from ProQuest database.

Moodle. (2011b). Moodle statistics. Retrieved October. 26, 2012,from http://moodle.org/stats/

Moore, M. \& Kearsley, G. (1996). Distance education: A system view. Belmont, CA: Wadsworth.

Newton, R. R. (2000). Tensions and models in general education planning. Journal of General Education, 49(3), 165-181

Nozawa, K. (2011). To Moodle or not to Moodle: Can it be an idea e-learning environment? Political Science, 18(3), 289-312.

Pascarella, Ernest T., \& Terenzini, Patrick T. (1991). How College Affects Students. San Francisco: Jossey-Bass

Report of the Committee e on General Education. (2005). Faculty of arts and sciences, Harvard University. Retrieved Sept. 26, 2012, from http://www.math.harvard.edu/chairmandocs/009_Report_of/general_education_nov_05.pdf

Report of the Task Force on General Education. (2007). Faculty of arts and sciences, Harvard University. Retrieved Sept. 24, 2012, from http://www.sp07.umd.edu/HarvardGeneralEducationReport.pdf

Smith, A. F. (2009). Learning outcome and student learning English as a second language. Networks, 11(2), 1- 13.

Voparil, C. J. (2007). John Dewey and practical liberal education: some ides for general education reform. The Fourth Annual APSA Conference on Teaching and Learning.

Williams, B. C. (2005). Moodle : For Teachers, Trainers, and Administrators. Creative Common NonCommercial copyright. New York.

Wu, W. S. (2008). The application of Moodle on an EFL collegiate writing environment. Journal of Education and Foreign Languages and Literature, 7, 45-56. 